\title{
Программы формирования городской среды: проблема привлечения ресурсов в объекты символической инфраструктуры Ижевска
}

В последние годы программы формирования комфортной городской среды реализуются во всех регионах России. Благоустройство городских пространств стимулировало новый этап обсуждений принципов организации городской инфраструктуры, состояния историко-культурного наследия в провинциальных городах, а также потребностей и степени активности разных категорий жителей. В Ижевске, типичном городе уральской провинции, вместе с активизацией практик внутреннего туризма, возобновилась дискуссия об уникальных особенностях города. В Ижевске сохранилось всего несколько построек старше начала XX в. Город активно строился в 1950-1960-е гг. С начала 2000-х гг. предпринимаются меры по сохранению отдельных исторических зданий, а с 2017 г. реализуются проекты благоустройства по программе национального проекта "Формирование комфортной городской среды". Ожидания, связанные с экономическими выгодами от развития внутреннего туризма, предполагали создание визуальных маркеров "уникальности" и "привлекательности". Но ресурсные ограничения побуждают представителей органов власти использовать возможности частного инвестирования. Это, в свою очередь, предполагает коммерческое использование общественных пространств или исторических объектов, что иногда не совпадает с ожиданиями и мнением ижевчан. Проблема, исследованию которой посвящена настоящая статья, заключается в противоречии между необходимостью привлечения дополнительных ресурсов для интенсификации символической ценности городского пространства и структурными сложностями, препятствующими реализации ресурсного потенциала. Изучались представления о соотношении коммерческих интересов и задач формирования городской инфраструктуры, сложившиеся в среде экспертов по вопросам развития города. Предполагалось, что финансовые и управленческие аспекты развития урбанизированного пространства будут опираться на множественность представлений о городе и об образе жизни горожан.

Цель исследования состоит в выявлении социальных условий, в которых инвестирование частного капитала и ресурсы активности горожан могут әфффективно использоваться. Было выявлено две категории горожан, активность которых позитивно оценивают эксперты в сфрере городского планирования, - это предприниматели и городские активисты. Задачи исследования связаны с описанием способов участия каждой из выделенных категорий в программах развития городского пространства.

В первом разделе статьи анализируется әвристический потенциал и ограничения концепции "машин роста" Х. Молотча о координации интересов экономических и политических элит в рамках проектов городского развития. Оценивается применимость концепции "машин роста" к ситуации в регионах России. Второй раздел посвящен описанию форм соотношения коммерческих интересов с символическими смыслами в культурных проектах. В третьем разделе оценивается степень вовлеченности горожан в процессы принятия решений по формированию комфортной городской среды.

\author{
(C) Власова T. A., 2021
}

ВЛАСОВА Татьяна Анатольевна, канд. филос. наук, доцент кафедры социологии Удмуртского государственного университета (2. Ижевск). E-mail: tavlasova@yandex.ru

Исследование выполнено в рамках проекта Программы президентских грантов № 19-2-021122 "Дерябинские ассамблеи: Межрегиональный форум исторических городов-заводов Урала и Поволжья" 
Эмпирической базой исследования стала серия интервью $(\mathrm{n}=30)$ с экспертами в области городского развития. Интервью были собраны в период с октября 2019 по январь 2020 г. В 2020 г. отмечалось несколько юбилейных дат, среди которых 260-летие Ижевска, 100-летие государственности Удмуртии. Мероприятия, посвященные этим событиям, трансформировались в исследовательский проект, в котором принимали участие работники центральных учреждений культуры города. Отбор әкспертов основывался на процедуре рейтингования: на начальном этапе три участника проекта, представляющие ведущие учреждения культуры Ижевска и общественные движения Удмуртской Республики, составили список экспертов. Преимущество при формировании окончательного перечня информантов отдавалось тем, кто находился во всех трех списках. В дальнейшем пул информантов пополнялся с учетом рекомендации других участников исследования по методу "снежного кома". В рамках проекта также был проведен опрос. И, хотя в статье специально не анализируются его результаты, они оказали влияние на интерпретацию данных качественного исследования.

\section{"Машины роста" и культурные индустрии: коммерция и символические ресурсы}

Результаты масштабных программ развития городов Европы и США были концептуализированы в 1970-х в рамках теории "машин роста" Х. Молотча. "Рост" рассматривался как комплекс экономических показателей, включающих увеличение населения, строительство новых кварталов, активизацию деловой жизни [15, с. 310]. Успех программ "роста" зависел от сотрудничества органов управления и крупных компаний. Хотя эти основные игроки приветствовали проявление частной инициативы, но такой, которая не противоречила их интересам. Кондрликт интересов представителей бизнеса и власти, с одной стороны, и групп активистов низовых общественных движений - с другой, стимулировал появление критики концепции "роста". Критика велась представителями среднего класса, связанными, прежде всего, с интеллектуальным трудом. Для этой категории акторов было наиболее очевидно, что цели экономического "роста" как универсальной градостроительной политики могут противоречить задачам сохранения уникальных особенностей отдельных районов или целых городов. Реакцией на критику стала установка на развитие "культурных индустрий".

Д. Хезмондалш определял феномен "культурных индустрий" как комплекс социальных институтов, которые участвуют в производстве социальных смыслов [12, с. 27], поэтому они также могут быть названы креативными. Коммерческие и государственные организации, а также организации третьего сектора (НКО и НГО), которые составляют отрасль креативных индустрий, концентрируются в городах. В 1980-1990-х гг. пришло понимание того, что креативные индустрии создают культурное разнообразие, положительно влияющее на развитие туризма. При этом мировой опыт показывает, что в ходе реализации туристических проектов и развития креативных индустрий доминировали именно коммерческие интересы [12, с. 194]. На уровне риторики культурных изменений стейкхолдеры апеллировали к задачам создания новых рабочих мест, интересам локальных сообществ, демократизации и доступности пространства для всех категорий граждан. Но при реализации программы происходила консолидация политических и экономических элит, и их интересы доминировали.

Опыт европейских стран показывает, что при экспансии коммерческих стратегий в сфреру культуры выигрывает бизнес, прежде всего строительные фирмы. Представители крупного бизнеса получают шанс первыми занять благоприятное для их деятельности место, получить некоторые фрормы бюджетного фринансирования, а затем воспользоваться прибылью от функционирования культурных индустрий, соблюдая видимость компромисса с органами местной власти и институтами гражданского общества [12, с. 200]. В 1990-е г. культурная политика в европейских городах реализовывалась в виде "культурных кварталов", которые одновременно были формой коммерческих инвестиций и элементом государственного протекционизма.

У политики развития городов в качестве символически означенного пространства были как достижения, так и неудачи. К первым можно отне- 
сти интенсификацию идеи культурного разнообразия, опирающегося на локальные особенности стран и городов. Основное противоречие раскрывается в соотнесении процессов формирования культурных индустрий и перспектив промышленного развития. Дж. Викери, анализируя пример Ковентри в Великобритании, указывает, что инициаторы проектов реконструкции городских пространств отдавали предпочтение масштабным объектам, ограничивая потребности низкоресурсных профессиональных групп, таких как художники или музыканты. Кроме того, амбициозные объекты, часто построенные в центре города, оставались недоступными для маргинальных групп населения [4, с. 230]. По мнению Ш. Зукин, стремление муниципальных органов управления использовать символику доступа/исключения в общественных пространствах само по себе указывает на принятый порядок: что демонстрируется, а что скрыто от взгляда; какие категории горожан приветствуются в качестве посетителей, а какие - нет [8, с. 24-25]. Сходную мысль высказывал Д. Харви, признавая, что социальные группы стремятся занять городское пространство, которое само по себе является ресурсом, а также может содержать ресурсные объекты [11, с. 85].

Оптимистичный взгляд заключается в том, что появление городских объектов или организация на месте исторической застройки музейных кварталов способствует оживлению экономики. Ш. Зукин замечает, что работа над символическим образом сама по себе признак экономического благополучия. Однако культурные проекты давали положительный экономический эфрфект в мегаполисах, в то время как небольшие города не получали импульса для развития других отраслей экономики. Города и регионы с устойчивым әкономическим потенциалом, развивая креативные индустрии, получали новые возможности благодаря инвестированию и вместе с тем формировали символическую основу для идентичности местных жителей. Достаточно успешным развитие креативных индустрий было в тех городских и сельских пространствах, где уже не было надежды на оживление промышленного производства $[11$, c. 125]. Но там специализация в сфрере туризма и досуга создавала для предпринимателей, которые вели бизнес в рамках креативных индустрий, дополнительные риски, особенно в периоды экономического спада, когда туристический поток сокращался.

Развитие общественных пространств в России также укладывается в логику неолиберальных установок, которые выражаются в стремлении органов региональной и местной власти разделить расходы на организацию городского пространства с коммерческими структурами. Фронтирами между представителями муниципалитетов, бизнесменами и активистами общественных движений становятся общедоступные пространства, такие как парки [1; 19] и исторические кварталы [6]. При переходе к анализу российской ситуации становится очевидно, что общественные объединения, по сравнению с европейскими активистами, ограничены в своем ресурсном потенциале. Это проявляется на примере градозащитного движения в Санкт-Петербурге. Символическим основанием для идеологии активистов городских движений является комплекс представлений об исключительной культурной ценности архитектурного и историко-культурного облика Санкт-Петербурга. Расширение масштабов строительства поставило вопрос о сносе некоторых зданий, которые воспринимались жителями как аутентичные исторические памятники. Б. Гладарев отмечает, что участники разных общественных объединений и даже члены одной группы редко стремятся к достижению компромиссов. Сложности возникают также при взаимодействии с государственными органами управления и политическими партиями. Общественные градозащитные движения подчеркивают свою аполитичность, чтобы не потерять доверие общественности [6, с. 129-130]. Не исключено, что для участников такая позиция становится "спасением" от репрессивных последствий. В сфере градозащитного активизма доминируют краткосрочные и ситуативные социальные связи.

Значительная часть градостроительных решений в крупных городах демонстрирует специфику формирования альянсов общественных активистов, власти и бизнеса. Как показывает исследование Е.В. Тыкановой и A.M. Хохловой, в условиях дефицита городских бюджетов власти делают ставку на коммерческие проекты, большая часть которых ориентирована на рост доходов от 


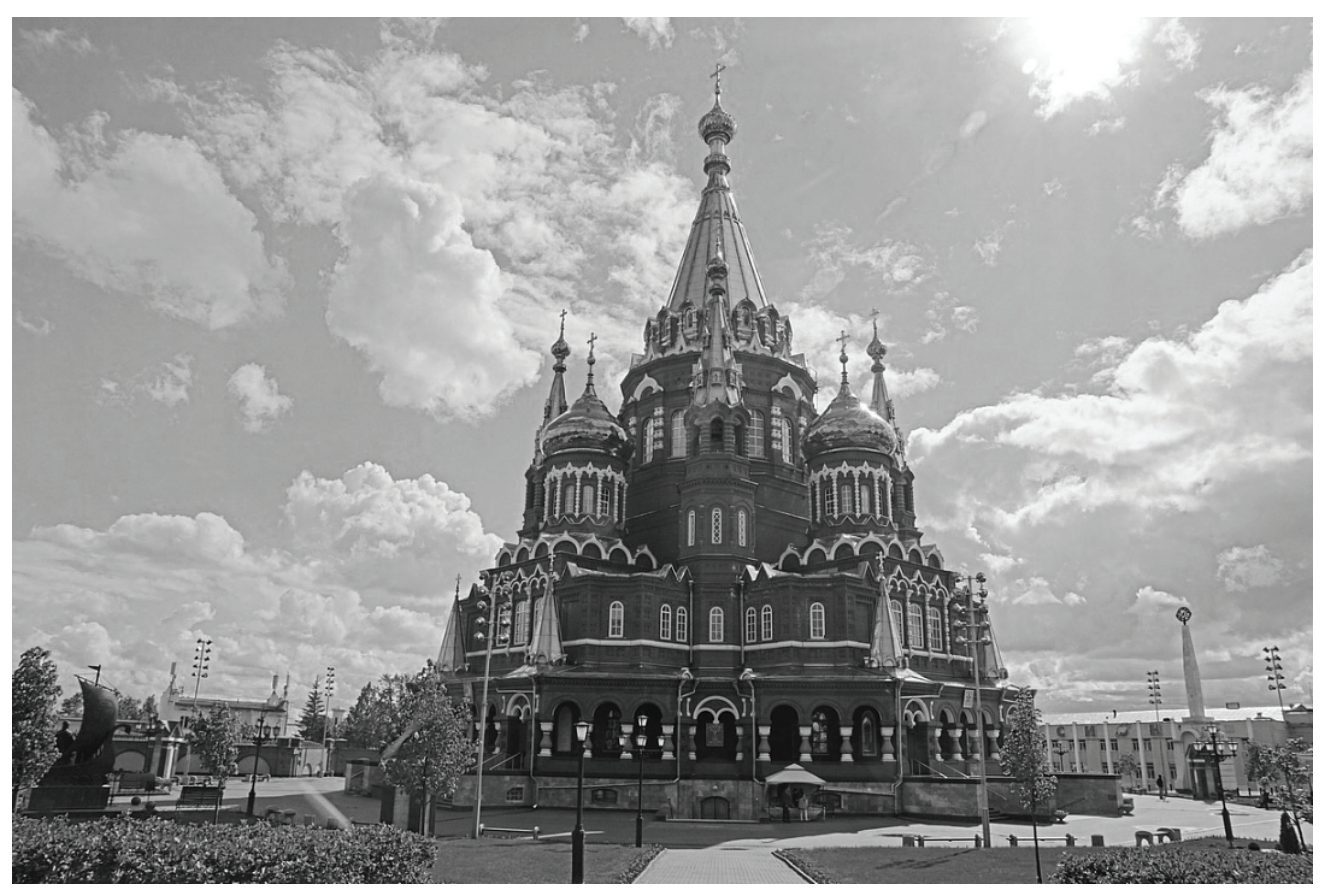

Фото 1. Свято-Михайловский собор, 2018 г. Источник: Архив ВООПИК.

туризма и развитие крупного бизнеса. Например, в Санкт-Петербурге после сноса старой застройки появляются коммерческие объекты, чаще всего торговые центры. Там, где сосредоточены признаваемые исторические и архитектурные ценности, бизнесу и власти особенно легко скооперироваться. Часто союзы основаны на неформальных связях, как дружеских, так и родственных. [10, с. 245]. В ситуациях противостояния вокруг сноса исторических построек власти находятся на стороне застройщиков. В контексте неолиберальных редорм местного управления происходит децентрализация политической ответственности [9, с. 30], выражающаяся в том, что в ходе развития городских пространств власти делают выбор в пользу ресурсных игроков иногда в ущерб интересам обычных граждан. Например, строительство ледяного городка "Сказбург" в период новогодних праздников 2017/2018 гг. в Ижевске стало примером противоречий между приватизацией общественного пространства с целью извлечения коммерческой прибыли и притязаниями на общедоступность [3, с. 464].

$\mathrm{X}$. Фрёлих описывает процессы вынужденной политизации, характерные для крупных городов, как результат неолиберальных установок власти, которые нацелены на максимизацию прибыли от городских изменений [13, c. 192]. Несогласие с инициативами по благоустройству быстро принимает политическую форму и приводит к выражению недоверия к муниципалитетам.

Исследования практик общественного согласования городских изменений в России и за рубежом демонстрируют взаимосвязь объема экономических и символических ресурсов, которыми обладают разные социальные агенты, с одной стороны, и готовность к согласованию своих интересов - с другой. Большинство примеров, получивших аналитическое осмысление, фрокусируется на результатах исследований в крупных городах. В провинции, где в большей степени выражен дефицит ресурсов, проявляется специфика взаимодействия власти и бизнеса, а также существуют собственные механизмы принятия решений относительно развития городского пространства. 


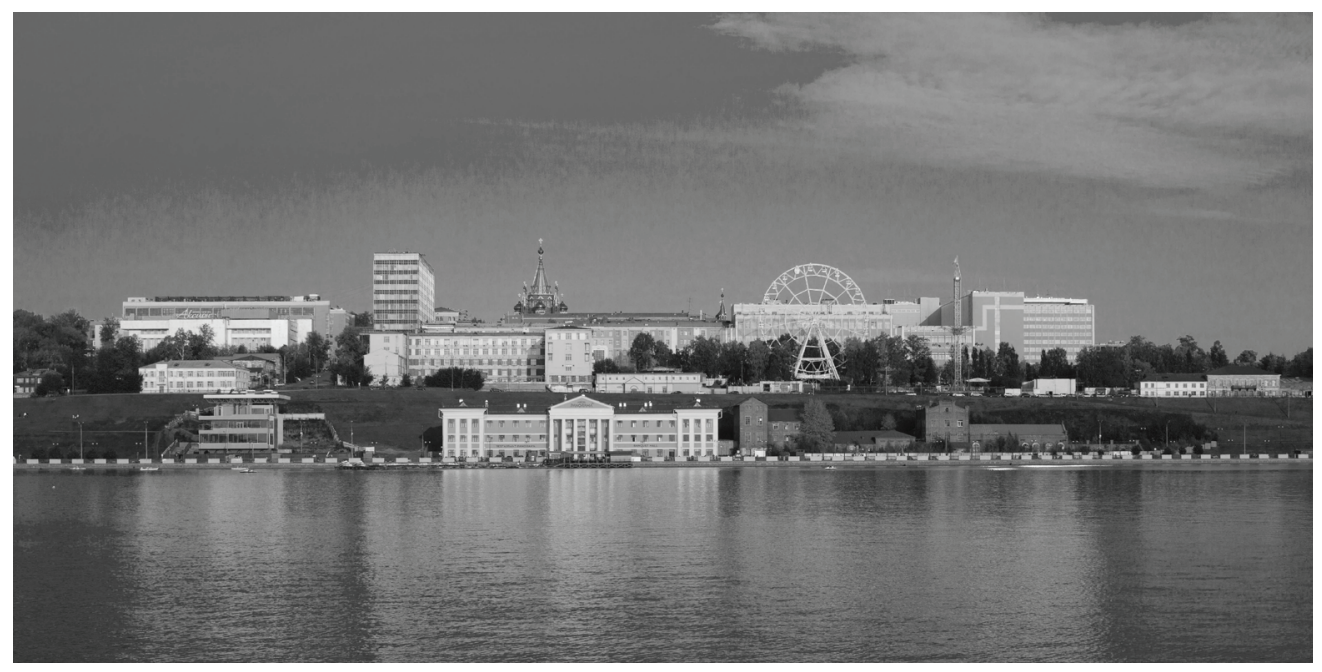

Фото 2. Вид с Ижевского пруда на набережную. Источник: Фото А. Ермолаева.

\section{Как работают "машины роста" в российской провинции?}

Эксперты, принимавшие участие в серии интервью, оценивали Ижевск как пространство, требующее изменений, которые не происходят из-за ресурсных ограничений. Проблема трактовалась как противоречие между коммерческим использованием городских объектов и установкой на воспроизводство исторических и символических смыслов. В период с 2000 по 2020 гг. в Ижевске был реализован ряд программ городского развития. По словам информантов, в 2000-х приоритет отдавался различным формам федеральных программ, частный капитал имел второстепенное значение. В то время были реконструированы исторические памятники, а также был восстановлен ранее утраченный Свято-Михайловский собор (ббото 1)². В 2010-е больше внимания уделялось обустройству общественных пространств: набережная пруда (g6ото 2), скверы, парки. Этому способствовала реализация приоритетного национального проекта "Формирование комфортной городской среды", одно из требований которого - согласование городских изменений с общественностью - предполагало вовлечение в обсуждение горожан.

Смещение внимания муниципальных органов в сфреру обустройства общественных пространств создало дополнительные сложности в вопросах содержания исторических зданий, так как средств на реставрацию и реконструкцию не выделялось. Представители муниципалитета подчеркивали, что все больше ресурсов необходимо для обеспечения эксплуатации стремительно изнашивающейся инфраструктуры жилого фонда:

У нас захлебываются специалисты от такого количества обрашений. $Я$ недавно сделал статистику. И в некоторых отделах у нас получается 98 писел-ответов в месяи на одного человека (муж., архитектор, сотрудник муниципального управления).

Первоочередной задачей муниципалитета является содержание жилого фонда, которое требует все большего объема ресурсов, а не реконструкция старых зданий. Отдавая приоритет решению коммунальных проблем, представители муниципальных органов управления рассчитывают на те возможности, которые, по их представлениям, имеет бизнес.

Информанты, представлявшие различные профессиональные группы, которые были связаны с сохранением историко-культурного наследия, в своем отношении к вопросам его коммерческого использования разделились на две категории. Эти категории мы можем условно назвать "оптимистической" и "пессимистической". Сторонники первой позиции полагали, что привлечение бизнеса в сфреру культуры не только возможно, но уже активно реализу-

1 Все фотографии предоставлены издательством "Монпоражён" (г. Ижевск) 


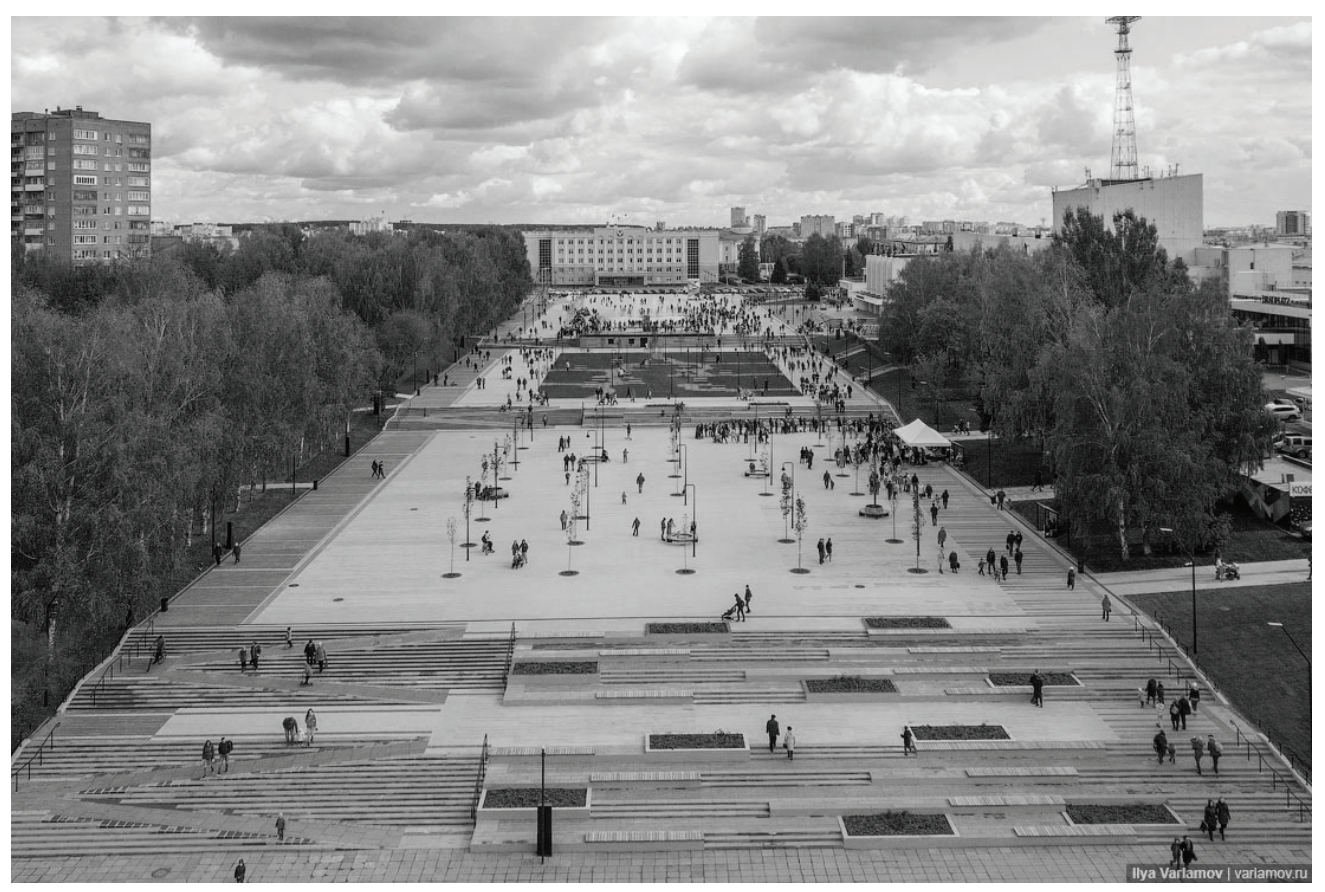

Фото 3. Центральная площадь, 2019 год. Источник: Фото И. Варламова

ется. К этой категории относятся информанты, работающие в региональных и муниципальных органах власти, а также в некоммерческих организациях, связанных с проектами благоустройства городской среды. Реконструированные (Центральная площадь (фбото 3)) или вновь созданные (Сквер оружейника Драгунова (ф6ото 4)) общественные пространства действительно быстро "обрастают" кафе, лавками и магазинчиками. Пространство "Открытый сад" (g6ото 5) было создано как девелоперский проект для дальнейшей застройки группы компаний "Острова". В последние годы в частную собственность были переданы знаковые для ижевчан здания, которые новые владельцы реконструировали. Так, в 2018-2020 гг. здание бывшего Индустриального техникума стало гостиницей, а здание бывшего кинотеатра "Дружба" - офисным центром (б6ото 6). Оба здания построены в 1950-е гг. и не относились к объектам историко-культурного наследия. Информанты-чиновники подчеркивали, что при всех сложностях, сопровождающих реконструкцию и перепрофилирование этих зданий, опыт можно оценивать как позитивный. Те же информанты возлагали надежды на перспективу появления инвесторов из других регионов, высказывая убеждение, что конкуренция в среде столичного предпринимательства сделает привлекательными инвестиционные проекты в провинции:

Мои коллеги в Москве говорили, что в регионы готовы заходить инвесторьь. (...) Я на самол деле думаю, что сейчас в Москве, в Питере этот рынок будет плюс минус в скором врелени перенасыщен, и уже люди понимают, что регионы - это следующая ступень (жен., помощник руководителя региона).

Таким образом, позитивная риторика была связана с инвестиционными ожиданиями и результатами действия "машин роста" в коммерческой сфере. Но все информанты, имевшие такие ожидания, не имели практического опыта работы с историко-культурным наследием.

Скептическое отношение к возможности привлечения бизнеса в сфреру культуры характерно для тех информантов, у которых был опыт проектов, связанных с объектами историко-культурного наследия. При этом работники учреждений культуры и представители академических профессий просто констатировали как недостаток финансирования, так и отсутствие интереса 


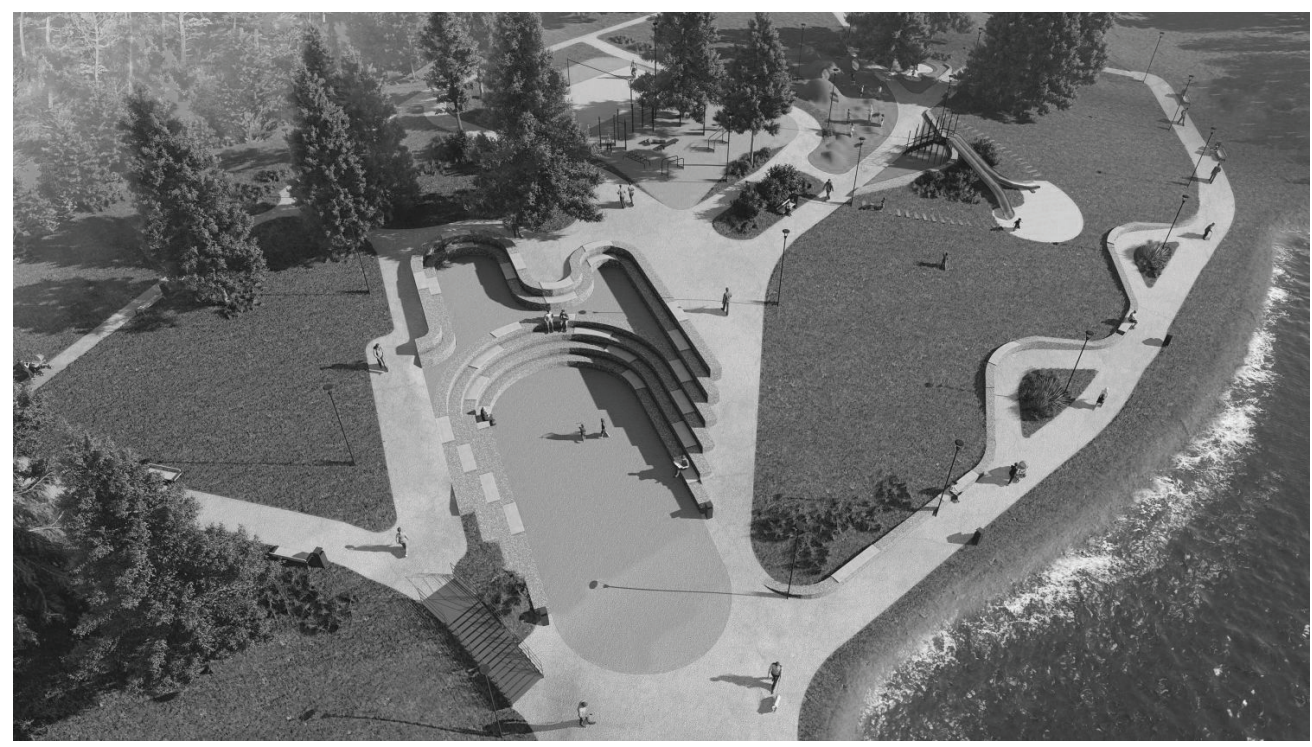

Фото 4. Проект сквера Оружейника Драгунова.

Источник: Изображение предоставлено Центром территориального развития УР

у предпринимателей. Работники сфреры культуры, которые консультировали проекты реконструкции в Ижевске, делали акцент на противоречиях, возникающих из-за расхождения интересов предпринимателей и "хранителей истории". Рассчитывая на коммерческое использование исторических зданий, собственники, во-первых, используют материалы, которые могут иметь разрушительный эффект для интерьера и внешнего облика зданий, а во-вторых, ориентируются на принципы социальной эстетики внешнего оформления, характерные для современного стиля.

В интервью описывались примеры, когда результаты реконструкции были отрицательно оценены специалистами-историками:

Понятно, что реставраиия значительно удорожает содержание здания-палятника, кто-то старается избежать или делает плохо (жен., сотрудник республиканского учреждения культуры, специалист по проектной деятельности).

Информанты-бизнесмены также были сторонниками скептической позиции. Те предприниматели, которые пытались реставрировать здания для последующего коммерческого использования, и сами были разочарованы результатом:

Но у нас был опьт одного исторического как бы здания. Вот, мне кажется, что тал не очень мь можел гордиться. Хотя, конечно, тали обошлось, практически обошлось без достройки и придульвания. (...) Но по толу, как выглядит фбасад витринь, мне тоже не нравится. Не получилось, как бы пряло как бы, не знаю, такой вот шедевральности. Слишкол пахнет новыли. Хотя очень старались (муж., предприниматель, руководитель группы организаций ООО "Острова", девелопер).

Взаимная настроенность на сотрудничество в начале проекта реконструкции не реализовывалась на практике. Сохранение старинного облика зданий требовало совмещения указаний от архитекторов и историков, иногда противоречащих с целями их коммерческого использования. Информанты-предприниматели детально описывали сложности с оформлением документации и согласованием законодательных нюансов. Решение большинства таких проблем требует контактов с представителями муниципальной власти. Поэтому бизнесмены ориентированы на контакт с управленцами, а не с историками или специалистами по охране объектов культуры, что способствует укреплению провинциальных "машин роста". Обилие технических и организационных сложностей в обустройстве коммерческого объекта все чаще 


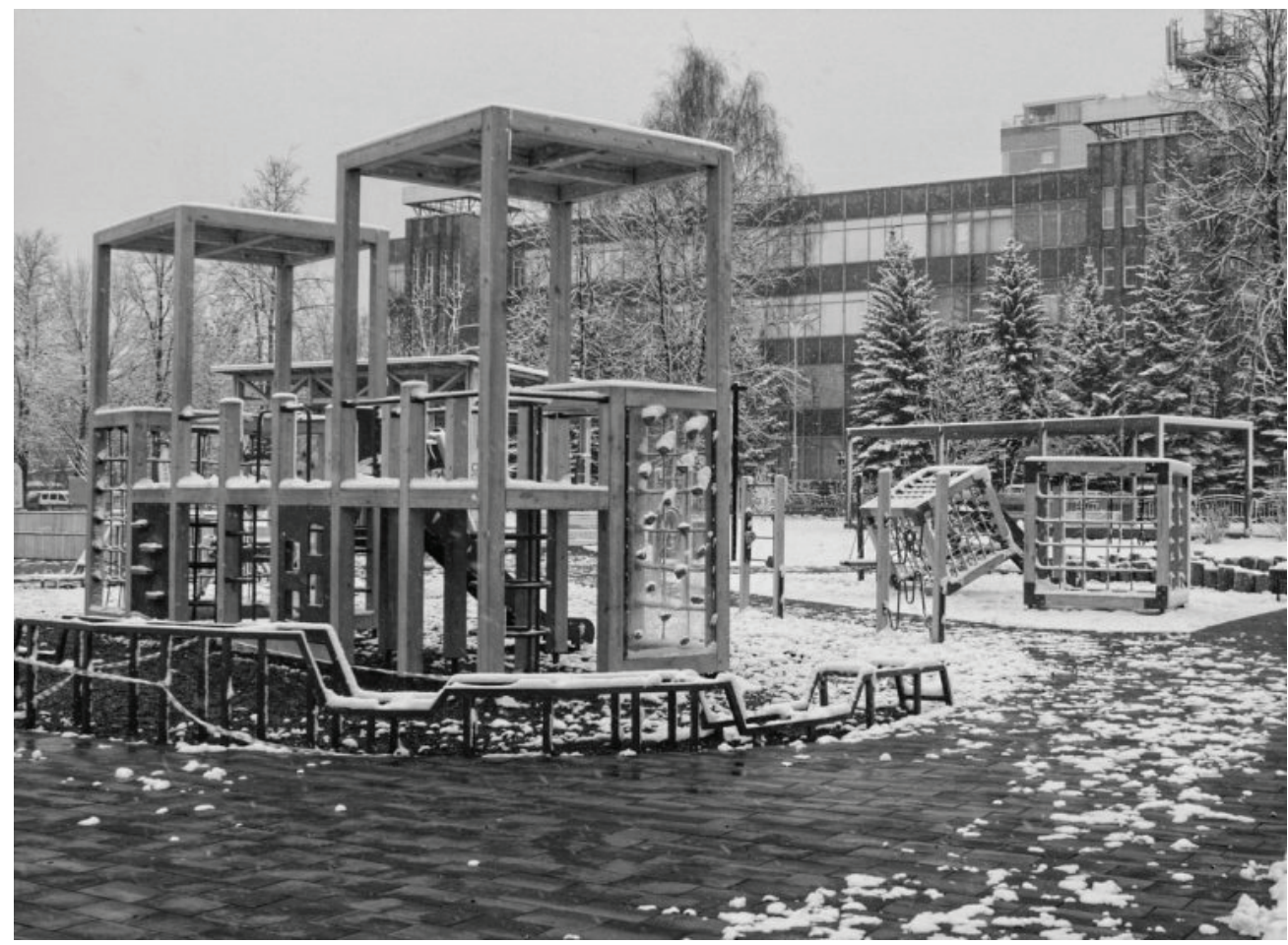

Фото 5. Пространство "Открытый сад". Источник: Фото М. Смагина

заставляет предпринимателей отдавать предпочтение зданиям без исторического прошлого:

Я бы на жилой дол вообще не вставал. С другой стороны, у нас есть прилер - двухэтажное здание. Тал на второл этаже в 2014 году министерство сидело, и вот уже 5 лет мы не можел его запустить, потол, что оно под защитой палятников и это сложно (муж., предприниматель, руководитель группы компаний "Велком групп").

В практике некоторых информантов были другие случаи, когда объявлялся сбор средств, но никогда не удавалось набрать нужную сумму. Так случилось с инициативой изготовления копии боевого знамени Ижевской дивизии. Несмотря на неудачи краудфандинговых инициатив, информанты подчеркивали необходимость поддерживать даже эпизодические проявления активности горожан, потому что только немногие из них откликаются на инициативы со стороны учреждений культуры или общественных движений.

Особый интерес представляют случаи, когда возникают альтернативные механизмы сбора средств на ревитализацию исторического объекта. Таким кейсом в рамках настоящего исследования стал театр Les Partisans. Самодеятельный театр длительное время не получал бюджетного фринансирования и существовал за счет сборов, грантов и спонсорской помощи. В 2018 г. театру было предоставлено помещение, примыкающее к одному из самых старых зданий Ижевска - Генеральскому дому (построен в 1857 г.) (g6ото 7). Помещение использовалось для подсобных нужд, поэтому для проведения спектаклей требовался немедленный ремонт. Суммы, которые вносили горожане, были небольшими. Более значительную помощь оказали предприниматели:

И за две недели мы влесто 140 тыссяч собрали 250. (...) Нали пологали и простыл зрители, которые тали по тысяче переводили, и кто-то из бизнеса, которые тал оплачивали стройлмтериаль, уже на более серьёзные суллы. И вот нас это так удивило, что вот мы почувствовали, что вот мы нужны (муж., режиссер независимого театра).

В благодарность за помощь актеры театра участвовали в мероприятиях спонсоров, но далеко не все предприниматели нуждались в такой реципрок- 


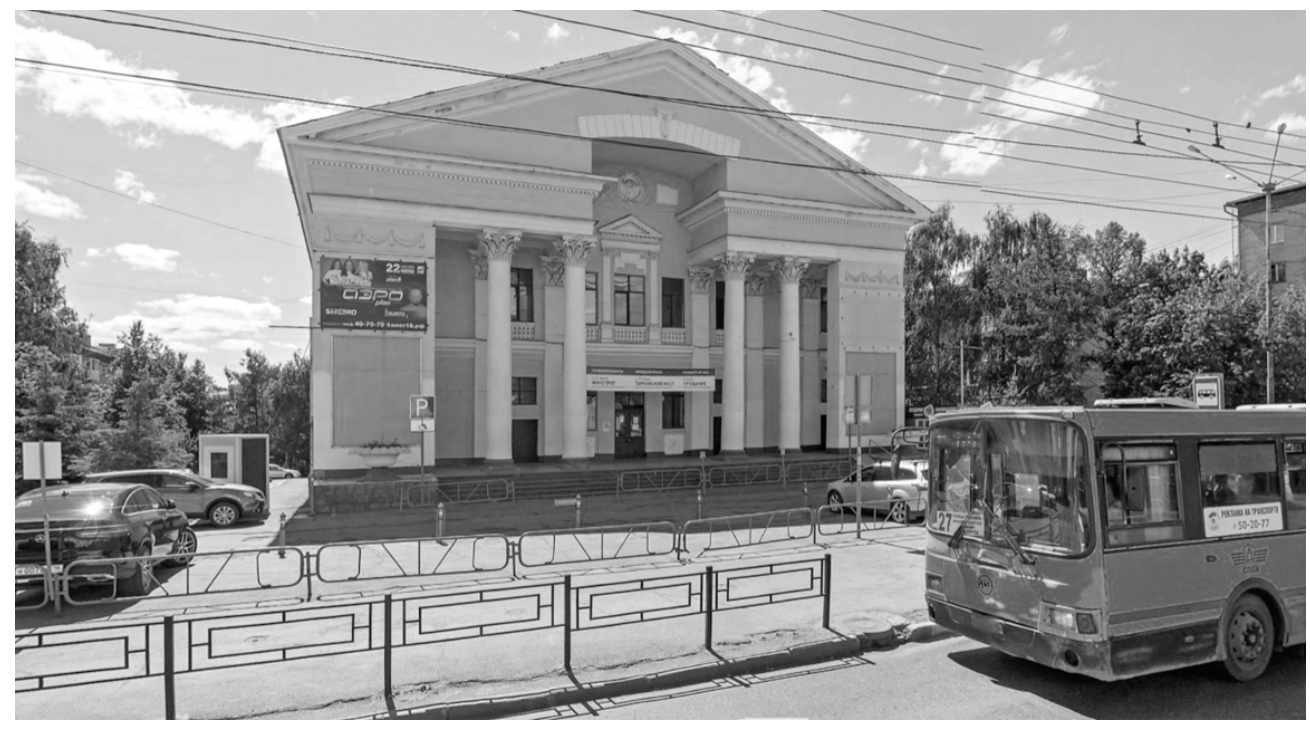

Фото 6. Здание бывшего кинотеатра "Дружба", ныне офисный центр.

Источник: Фото с сайта Яндекс. Карты

ности. Некоторые информанты-бизнесмены сообщали о том, что они помогали театру по причине личной заинтересованности, то есть "по дружбе". Система давно сложившихся личных связей чаще всего используется участниками исследования при поиске фринансирования и считается самой результативной. Хотя в условиях кризиса объем ресурсов, которыми может поделиться бизнес, уменьшается: "У меня много друзей. Я могу прийти попросить, но всё реже и реже дают" (муж., художник). С другой стороны, в сети сплоченных личных связей сложно реализовать проекты, которые приходят извне, даже если они проработаны и имеют детальные обоснования.

Еще одной причиной поддержки самодеятельного театра со стороны бизнесменов является фрактор его независимости от бюджетного финансирования, а значит, дистанцированность от местных органов управления. Необходимость кооперащии с органами власти в практиках, соответствующих логике "машин роста", компенсируется действиями, позволяющими дистанцироваться от официальной политики. Однако эта позиция лишь неявно улавливается в риторике информантов-бизнесменов и требует более глубокого изучения.

\section{Активность горожан как фактор программ развития городской среды}

В настоящее время устоялась практика публичных согласований городских изменений. Альтернативой коммерциализации для информантов выступает практика вовлечения местных жителей в процессы городского планирования. Современные урбанистические исследования основываются на предположении, что горожане заинтересованы в тех решениях, которые будут направлены на обеспечение комфортной городской жизни, а не на вопросы экономии бюджетных средств или извлечения прибыли. Р. Грац отмечала, что в США в 1990-е гг., когда появились примеры неудачных реконструкций, укрепилось представление о решающей роли местных сообществ в ходе принятий решений как о новом строительстве, так и о реставрации исторических кварталов и зданий. Сообщества или отдельные активисты при этом опирались на собственные ресурсы, как финансовые, так и символические [16; 17]. Органы местной власти имеют собственные экономические интересы, связанные с әффректами джентрификации: повышение стоимости недвижимости, оживление деловой активности. В ходе реализации определенной городской политики для нее формируется специфическая идеология, с опорой на мифологию, нацеленная на консолидацию локальных и соседских сообществ. Иде- 


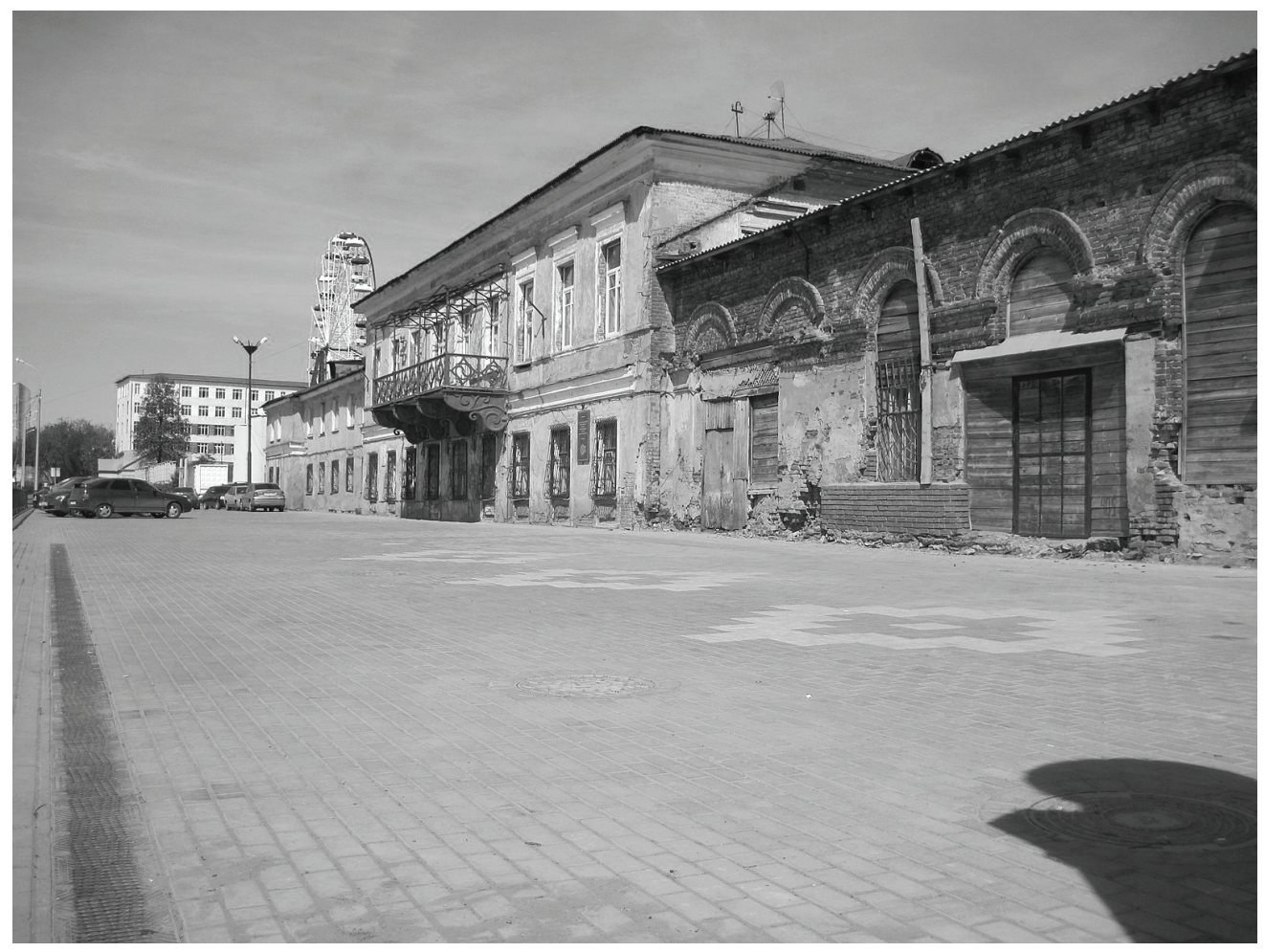

Фото 7. Здание Генеральского дома, в пристрое размещен независимый театр Les Partisans. Источник: Фото Yan.gorev

ологические концепты порождают обобщенные категории для разных групп населения. Благодаря мифологизированному дискурсу городские практики артикулируются и служат для идентификации горожан. Использование мифологем приобретает особый смысл, когда необходимо достичь сотрудничества между различными акторами в условиях децентрализации современной европейской политики. Позитивный пример әффективного сотрудничества городских властей и местных сообществ был реализован во фрранцузском Нанте. Стратегия управления в Нанте строилась на предоставлении дополнительных ресурсов частным девелоперам, работавшим в сотрудничестве с общественными деятелями, чтобы способствовать большей "гибкости" институциональных рамок [14, с. 97]. В то же время в идеологическом дискурсе были уязвимые места, появлялись соперничающие дискурсы оппозиционных политических сил. Публичные обсуждения воспринимались как техника манипулирования общественным мнением.

В крупных городах России, а затем в провинции, постсоветские изменения создали основания для трансформации пассивных жителей в горожан, готовых принять ответственность и проявить гражданскую позицию. При этом проявляются особенности социально-политической ситуации, сложившейся в разных регионах.

Оценка информантами перспектив активизации жителей зависела от их мнения об отношении ижевчан к городу. Работники учреждений культуры констатировали рост интереса горожан к музейным выставкам и экспозициям, а также популярность просветительских лекций по истории Ижевска и пешеходных экскурсий по городу. В социальных сетях появляются группы, где участники делятся личными и семейными историями, а также фотографияями старого Ижевска. Стало больше тех, кто увлекается составлением семейной генеалогии и обращается в архивы. Руководитель архивной службы в ходе интервью отмечала и обратный эфффект: горожане приносят в архив документы, фотографии, которые, как они полагают, могут иметь значение для истории. 
Таким образом, формируется "спрос на историю". Однако все эти практики отражают индивидуальные интересы. Коммунальные практики, по мнению информантов, выражаются в действиях, имеющих общественное значение.

По словам информантов, в последние годы ижевчане демонстрируют растущую ответственность за состояние городских пространств, участвуя в субботниках по благоустройству и экологических мероприятиях. Информанты, работавшие в сфрере охраны памятников, отмечали, что горожан легче мобилизовать на разовые действия или решение тех проблем, которые активно обсуждаются в СМИ. Последним публичным событием 2019 г. стал митинг за сохранение бывшего здания Русского драматического театра, которое подлежало сносу из-за ветхости. Но чаще дело заканчивается на уровне дискуссий в социальных сетях.

Сотрудники музеев, выставочных центров и общественных объединений по охране историко-культурного наследия учитывали позицию тех горожан, кто проявлял интерес к культурным событиям Ижевска. Больше скепсиса проявляли информанты, работающие с массовой аудиторией. Они отмечали низкий уровень знаний об истории и культуре края, особенно у детей и молодежи. Участники исследования связывали это с двумя причинами: во-первых, с содержанием образовательных и просветительских программ в республике, а во-вторых, с отсутствием эмоциональной привязанности ижевчан к городу. Часть экспертов подчеркивали фрактор ограниченных ресурсных возможностей горожан в условиях небольших зарплат в регионе. Также высказывалась позиция о том, что муниципальные органы управления блокируют инициативы общественных объединений и отдельных граждан.

Особо выделим мнение информантов-бизнесменов, которые в качестве объяснительной модели использовали рассуждения о специфическом "менталитете дотационного региона", свойственном ижевчанам:

Поработай на предприятии, предприятие о тебе позаботится. Это передавалось из поколения в поколение, тал, да, лне, кажется, уже тал где-то в ДНК уже специальный тали белок сфорлировался... (муж., предприниматель в сфере ИТ).

Участие общественности в процессе обсуждения проектов городского планирования многие информанты считают формальностью, так как жители могут выбирать из ограниченного числа вариантов. Хотя проектные семинары проводятся регулярно и количество предложений от горожан, как замечали эксперты, "зашкаливает", их результаты остаются предметом для дискуссии. Эксперты из сферы муниципальных учреждений сожалели о том, что действительно полезных и конструктивных предложений немного. Другие информанты, вспоминая собственный опыт участия в проектных сессиях, замечали, что многие идеи просто не были услышаны, так как не соответствовали изначальным установкам организаторов.

Публичные обсуждения проектов развития городской среды разворачиваются в отношении небольших досуговых зон: парков, скверов, прогулочных маршрутов. Для оценки горожанам предлагаются проекты, которые прошли через "фольтр" муниципальных учреждений, отвечающих за благоустройство. Жители могут проголосовать за то, какие из уже подготовленных проектов будут реализованы в первую очередь. С другой стороны, нет каналов для критики или замечаний в отношении уже реализованных проектов. Занимая позицию обычных горожан, эксперты отмечали, что проекты благоустройства пространств отдыха выглядят однообразно. При этом в отношении зеленых зон города ведется диалог между представителями муниципальной власти, общественными объединениями и горожанами, в то время как интерес к сохранению историко-культурного наследия проявляется крайне слабо.

Информанты утверждали, что сформировалась потребность в инфраструктуре для общественных инициатив. Данные предложения эксплицитно или имплицитно указывали на необходимость актуализации разных видов формального и неформального общения горожан. 
В российских регионах складывается специфическая модель обеспечения социально-экономического роста. По сравнению со странами Западной Европы доминируют практики, где решающую роль играют органы управления различного уровня. Механизмы государственного регулирования часто ограничивают инициативы, связанные с коммерческим использованием городских объектов. Привлечение бизнеса идет успешнее в публичных городских пространствах (парках, скверах, набережной). Из-за законодательных ограничений и сложностей согласования предприниматели отказываются от инвестиций в сохранение исторических зданий.

Одновременно с этим часть информантов отмечала рост интереса жителей Ижевска к происходящим городским изменениям. С одной стороны, в публичной сфрере по данным опроса формируется спрос на новую "постиндустриальную" городскую среду, что выражается в желании чаще посещать театры, концертные залы, художественные выставки и галереи, интересе к пешим экскурсиям по городу и туристическим поездкам по республике [5]. С другой стороны, информанты констатировали слабый уровень развития инфраструктуры и практик волонтерского участия. Лишь часть экспертов отметили, что небольшое (но достаточно стабильное) число жителей участвуют в проектах благоустройства городских пространств (парков, скверов, прогулочных зон), и в меньшей степени они заинтересованы принимать участие в мероприятиях, связанных с сохранением и развитием историко-культурных объектов. Индрорманты отмечали, что на сегодняшний момент неэффективными оказываются механизмы меценатства, спонсорской помощи и проектного краудфандинга. Большая доля горожан, по данным опроса, выступает в первую очередь за сохранение бюджетного финансирования существующих заведений культурной индустрии, но лишь немногие из этих заведений непосредственно работают с историческим наследием или аккумулируют достаточный для развития бренда культурно-символический потенциал.

\section{Литература}

1. Абрамов Р.Н., Запорожец О.Н. Пространство любви и пространство заботы: практики народного освоения Царицыно // Царицыно: аттракцион с историей. М.: Новое литературное обозрение, 2014. С. 273-302.

2. Богатова О.А., Гусева Е.Н. Историческая память и этничность в городской архитектурной среде как фактор конструирования социальной идентичности населения столиц республик в составе Российской Федерации на примере Ижевска и Саранска // Вестник Удмуртского университета. Социология, Политология. Международные отношения. 2019. Том 3. № 4. С. 409-429.

3. Борисова О.А. Публичное пространство города как реализация горожан "права на город" // Вестник Удмуртского университета. Социология, Политология. Международные отношения. 2018. Том 2. вып.4. С. 459-465.

4. Викери Дж. Возрождение городских пространств посредством культурных проектов - синтез социальной, культурной и городской политики. // Визуальная антропология: городские карты памяти. Под ред. П. Романова, Е. Ярской-Смирновой. М.: ООО "Вариант", ЦГСПИ, 2009. С. 205-234.

5. Власова Т.А., Обухов К.Н. Ижевск 2020: опыт социологического исследования символического пространства города. Монография. Ижевск: Изд-во "Монпоражён", 2020. 124 c.

6. Гладарев Б. "Это наш город": анализ Петербургского движения за сохранение историко-культурного наследия // Городские движения России в 2009-2012 гг.: на пути к политическому. / Под ред. К. Клеман. М.:НЛО, 2013. С. 23-145.

7. Грац Р. (2008). Город в Америке. Жители и власти (В. Глазычев, Пер.). Общество Развития Родной Культуры.

8. Зукин Ш. Культуры городов. М.: Новое литературное обозрение, 2015. 424 с.

9. Семенов А.В. Корни травы: паттерны низовой городской мобилизации в России // Социологические исследования. 2019. № 12. С. 29-37.

10. Тыканова Е.В., Хохлова А.М. Городской политический режим в Санкт-Петербурге: роль реальных и воображаемых "машин роста" в борьбе за городское пространство. // Журнал исследований социальной политики. 2015. Том 13. № 2. С. 241-256.

11. Харви Д. Социальная справедливость и город. М.: Новое литературное обозрение, 2018. 440 с. 
12. Хезмондалш Д. Культурные индустрии. М.: Изд. дом Высшей школы экономики, 2014. 456 с.

13. Fröhlich Ch. Urban citizenship under post-Soviet conditions: Grassroots struggles of residents in contemporary Moscow. // Journal of Urban Affairs. 2020. Vol.42, No 2, P 188-202.

14. Grigg S., Howarth D., Feandeiro A. The logic and limits of "collaborative governance" in Nantes: Myth, ideology, and the politics of new urban regimes // Journal of Urban Affairs. 2020. Vol. 42. No. 1. P. 91-108.

15. Molotch H. The City as a Growth Machine: Toward a Political Economy of Place. // American Journal of Sociology. 1976. Vol. 82. No 2. P. 309-332. URL: http:// www.jstor. org/stable/2777096 (дата обращения 27.07.2020).

16. Polanska D.V. Going against institutionalization: New forms of urban activism in Poland // Journal of Urban Affairs. 2020. Vol. 42. No. 2. P. 176-187.

17. Vallbe J.-J., Magre J., Tomas M. Being Metropolitan: the effects of individual and contextual factors on shaping metropolitan identity. // Journal of Urban Affairs. 2017. Vol. 40. No. 1. P. 13-30.

18. Winter T. Clarifying the critical in critical heritage studies // International Journal of Heritage Studies, 2013. Vol. 19. No. 6. P. 532-545.

19. Zupan D., Budenbender M. Moscow urban development: Neoliberal urbanism and green infrastructures // Post-Socialist Urban Infrastructures. Publisher: Routledge, 2019. P. $125-141$.

\section{Транслитерация по ГОСТ 7.79-2000 система Б}

1. Abramov R.N., Zaporozhets O.N. Prostranstvo lyubvi i prostranstvo zaboty: praktiki narodnogo osvoeniya TSaritsyno // TSaritsyno: attraktsion s istoriej. M.: Novoe literaturnoe obozrenie, 2014. S. 273-302.

2. Bogatova O.A., Guseva E.N. Istoricheskaya pamyat' i ehtnichnost' v gorodskoj arkhitekturnoj srede kak faktor konstruirovaniya sotsial'noj identichnosti naseleniya stolits respublik v sostave Rossijskoj Federatsii na primere Izhevska i Saranska // Vestnik Udmurtskogo universiteta. Sotsiologiya, Politologiya. Mezhdunarodnye otnosheniya. 2019. Tom 3. № 4. S. 409-429.

3. Borisova O.A. Publichnoe prostranstvo goroda kak realizatsiya gorozhan "prava na gorod" // Vestnik Udmurtskogo universiteta. Sotsiologiya, Politologiya. Mezhdunarodnye otnosheniya. 2018. Tom 2. vyp.4. S. 459-465.

4. Vikeri Dzh. Vozrozhdenie gorodskikh prostranstv posredstvom kul'turnykh proektov - sintez sotsial'noj, kul'turnoj i gorodskoj politiki. // Vizual'naya antropologiya: gorodskie karty pamyati. Pod red. P. Romanova, E. YArskoj-Smirnovoj. M.: OOO "Variant", TSGSPI, 2009. S. 205-234.

5. Vlasova T.A., Obukhov K.N. Izhevsk 2020: opyt sotsiologicheskogo issledovaniya simvolicheskogo prostranstva goroda. Monografiya. Izhevsk: Izd-vo "Monporazhyon", 2020. 124 s.

6. Gladarev B. "EHto nash gorod": analiz Peterburgskogo dvizheniya za sokhranenie istoriko-kul'turnogo naslediya // Gorodskie dvizheniya Rossii v 2009-2012 gg.: na puti k politicheskomu. / Pod red. K. Kleman. M.:NLO, 2013. S. 23-145.

7. Grats R. (2008). Gorod v Amerike. ZHiteli i vlasti (V. Glazychev, Per.). Obshhestvo Razvitiya Rodnoj Kul'tury.

8. Zukin SH. Kul'tury gorodov. M.: Novoe literaturnoe obozrenie, 2015. 424 s.

9. Semenov A.V. Korni travy: patterny nizovoj gorodskoj mobilizatsii v Rossii // Sotsiologicheskie issledovaniya. 2019. № 12. S. 29-37.

10. Tykanova E.V., KHokhlova A.M. Gorodskoj politicheskij rezhim v Sankt-Peterburge: rol' real'nykh i voobrazhaemykh "mashin rosta" v bor'be za gorodskoe prostranstvo. // ZHurnal issledovanij sotsial'noj politiki. 2015. Tom 13. № 2. S. 241-256.

11. KHarvi D. Sotsial'naya spravedlivost' i gorod. M.: Novoe literaturnoe obozrenie, 2018. $440 \mathrm{~s}$.

12. KHezmondalsh D. Kul'turnye industrii. M.: Izd. dom Vysshej shkoly ehkonomiki, 2014. $456 \mathrm{~s}$

13. Fr $\square$ hlich Ch. Urban citizenship under post-Soviet conditions: Grassroots struggles of residents in contemporary Moscow. // Journal of Urban Affairs. 2020. Vol.42, No 2, P $188-202$.

14. Grigg S., Howarth D., Feandeiro A. The logic and limits of "collaborative governance" in Nantes: Myth, ideology, and the politics of new urban regimes // Journal of Urban Affairs. 2020. Vol. 42. No. 1. P. 91-108.

15. Molotch H. The City as a Growth Machine: Toward a Political Economy of Place. // American Journal of Sociology. 1976. Vol. 82. No 2. P. 309-332. URL: http:// www.jstor. org/stable/2777096 (data obrashheniya 27.07.2020).

16. Polanska D.V. Going against institutionalization: New forms of urban activism in Poland // Journal of Urban Affairs. 2020. Vol. 42. No. 2. P. 176-187. 
17. Vallbe J.-J., Magre J., Tomas M. Being Metropolitan: the effects of individual and contextual factors on shaping metropolitan identity. // Journal of Urban Affairs. 2017. Vol. 40. No. 1. P. 13-30.

18. Winter T. Clarifying the critical in critical heritage studies // International Journal of Heritage Studies, 2013. Vol. 19. No. 6. P. 532-545.

19. Zupan D., Budenbender M. Moscow urban development: Neoliberal urbanism and green infrastructures // Post-Socialist Urban Infrastructures. Publisher: Routledge, 2019. P. $125-141$.

Власова Т. А. Программы формирования городской среды: проблема привлечения ресурсов в объекты символической инфраструктуры Ижевска.

В статье анализируются перспективы и противоречия при реализации программ городского планирования в г. Ижевске. Эмпирической базой исследования стала серия интервью с экспертами из различных профессиональных сфер, связанных с принятием решений относительно развития городских пространств. Представлены два взаимосвязанных аспекта проблем обустройства городских пространств: кооперация бизнеса и муниципальной власти, а также способы вовлечения горожан. Результаты исследования подтверждают наличие определенного потенциала использования коммерческих решений для усложнения символического ландшафта города и возможности формирования новых вариантов проявления активности горожан.

Ключевые слова: городская среда, машины роста, символические ресурсы, инвестиции в сбберу культурь, активность горожан

Vlasova T. A. Urban environmental development programs: the problem of attracting resources to the objects of the symbolic infrastructure of Izhevsk.

The main topic of the article is the analysis of the contradictions in the city planning program realization in Izhevsk. The empirical basis for this research consists of the interviews with the expert of different professions that take part in desition making process behind the development of the city space. Two interconnected aspects of this problems are introduced: the cooperation between private businesses and local authorities, and the involvement of citizens in the projects. The results support the potential of using commercial solutions for increase in complexity of symbolic city scape and opportunities for the inclusiveness of urban citizens.

Key words: Urban environment, Growth machine, Symbolic resources, investments in the field of culture, citizens' activityz

Для цитирования: Власова Т. А. Программы формирования городской среды: проблема привлечения ресурсов в объекты символической инфраструктуры Ижевска // Ойкумена. Регионоведческие исследования. 2021. № 2. C. 82-95. DOI: 10.24866/1998-6785/2021-2/82-95

For citation: Vlasova T. A. Urban environmental development programs: the problem of attracting resources to the objects of the symbolic infrastructure of Izhevsk // Ojkumena. Regional researches. 2021. № 2. P. 82-95. DOI: 10.24866/1998-6785/2021-2/82-95 